\title{
Use of a Fractionated, Coupled Transcription-Translation System in the Study of Ribosomal Resistance Mechanisms in Antibiotic-producing Streptomyces
}

\author{
By MICHAEL J. CALCUTT $\dagger$ AND ERIC CUNDLIFFE* \\ Department of Biochemistry and Leicester Biocentre, University of Leicester, \\ Leicester LE1 7RH, UK
}

(Received 2 December 1988; accepted 26 January 1989)

The coupled transcription-translation system, formerly involving extracts of Streptomyces lividans, has been developed such that it functions with ribosomes (or their subunits) from at least 20 different Streptomyces species. This fractionated system has been used to investigate the antibiotic responses of ribosomes from various Streptomyces which synthesize inhibitors of protein synthesis. Of the 11 organisms included in this study, two strains possessed ribosomes that were specifically resistant to the autogenous antibiotic. These were Streptomyces pactum and Streptomyces karnatakensis, both of which produce pactamycin. Ribosomal subunit exchange analysis further demonstrated that resistance to pactamycin in those strains is due to some property of the $30 \mathrm{~S}$ ribosomal subunits.

\section{INTRODUCTION}

Coupled transcription-translation systems have proved invaluable in allowing the expression of prokaryotic genes to be studied in vitro. For example, they have been used to investigate such diverse processes as the role of cAMP in expression of the lac operon, (Chambers \& Zubay, 1969) the pleiotropic effects of guanosine polyphosphates (Yang et al., 1974; Cozzone, 1980) and the feedback regulation of ribosomal protein biosynthesis in Escherichia coli (for review, see Gourse et al., 1986). As techniques for the isolation and cloning of genes from other bacterial genera have progressed, the need for in vitro systems suitable for studying their expression has become acute. This is especially so for Streptomyces genes, since these do not normally function in heterologous hosts such as $E$. coli and consequently $E$. coli 'Zubay systems' are not suitable for studying their expression in vitro. For these reasons, a coupled transcription-translation system was developed in this laboratory (Thompson et al., 1984) using extracts of Streptomyces lividans, the currently-preferred host strain for interspecific gene cloning in Streptomyces. Furthermore, since transcriptional signals from a range of bacteria from both Gram-types appear to function in S. lividans (Bibb \& Cohen, 1982) it was initially hoped (and may indeed be so) that this in vitro expression system may be more catholic in its application than others derived from enteric bacteria.

Already, a wide diversity of genes have been expressed in $S$. lividans extracts. These include the determinants of resistance to antibiotics such as thiostrepton (Thompson et al., 1984) hygromycin B (Zalacain et al., 1987) and novobiocin (Thiara \& Cundliffe, 1988) and also genes involved in the biosynthesis of secondary metabolites such as puromycin (Vara et al., 1988). Also, the system has been used to visualize the intracellular form of a normally secreted protein (Bibb et al., 1987), a key protein involved in the life cycle of bacteriophage $\phi$ C31 (Sinclair \& Bibb, 1988) and a protein (' $69 \mathrm{kDa}$ ') of unknown function encoded on the Streptomyces cloning vector, pIJ350 (Thompson et al., 1984). One particularly interesting application of the system was its use in the identification of a cryptic gene in the $S$. lividans genome (Jones \& Hopwood, 1984). Thus, only one of three recombinant plasmids, each of which caused $S$. lividans to produce

$\dagger$ Present address: Department of Biochemistry, University of Missouri - Columbia, Columbia, Missouri 65212, USA. 
phenoxazinone synthase, actually encoded the $88 \mathrm{kDa}$ polypeptide. Moreover, this large protein, as synthesized in vitro, was precipitated by antibodies raised against the native protein, which argues powerfully for the fidelity with which the gene was expressed in the $S$. lividans extract.

To date, all studies reported using the Streptomyces coupled transcription-translation system have involved crude $S 30$ extracts of $S$. lividans according to the original recipe (Thompson et al., 1984), although we have been interested to observe that the protocol can also be applied to other Streptomyces species, for example Streptomyces erythraeus, Streptomyces spectabilis and Streptomyces virginiae (unpublished data from authors' laboratory). Nevertheless, the versatility of the system would be greatly enhanced if the extracts could be fractionated and, as appropriate, reconstituted with components derived, if need be, from different strains. On the one hand, this would enable transcriptional and translational aspects of gene expression to be studied independently in vitro. On the other, the possibly peculiar properties of specific components derived from any given strain could be studied in more detail. In the latter context, studies of antibiotic resistance mechanisms (e.g. those affecting ribosomes) come readily to mind. In what follows, we have proceeded to fractionate the in vitro gene expression system, paying particular attention to components involved in translation, and have illustrated the advantages of doing so in the context of studies involving resistance to pactamycin and other inhibitors of protein synthesis.

Pactamycin is a potent inhibitor of ribosomes from both prokaryotes and eukaryotes (for review, see Gale et al., 1981) although the action of the drug is severely attenuated in artificial protein-synthesizing systems directed by homopolynucleotides [e.g. poly(U)]. Quite why this should be so is not exactly clear, although there is good evidence derived from eukaryotic systems that the drug can preferentially affect the initiation of protein synthesis (Macdonald \& Goldberg, 1970; Lodish et al., 1971), a process that is not scored for in artificial systems. Against that, however, such data as are available from prokaryotic systems suggest that both initiation and elongation phases of protein synthesis may be equally sensitive to pactamycin (Cundliffe \& McQuillen, 1967; Tai et al., 1973).

Despite uncertainties concerning the precise mode of action of pactamycin, the drug evidently inhibits some crucial ribosomal function(s) since phylogenetic evidence reveals that its (uncharacterized) ribosomal binding site has been conserved throughout evolution. Consequently, the organisms that produce the drug (here, Streptomyces pactum and Streptomyces karnatakensis) must cope with the fact that they produce a particularly toxic metabolite. As yet, no pactamycin-resistance mechanism has ever been detected, let alone characterized, so that it has not been possible to predict a priori what survival strategies the producing-organisms might employ. Here, as the Streptomyces coupled transcription-translation system was fractionated and refined, we have used it to address the topic of resistance in the pactamycin-producing organisms.

\section{METHODS}

Bacterial strains and media. Streptomyces althioticus (UC 2343), Streptomyces karnatakensis (UC 5565) and Streptomyces sparsogenes (UC 2474) were obtained from Alma Dietz at the Upjohn Company, Kalamazoo, Michigan, USA. Streptomyces bottropensis (ATCC 25435) and Streptomyces pactum (NCIB 9445) were obtained from A TCC and NCIB respectively. Streptomyces lividans TK21 was provided by Professor D. A. Hopwood of the John Innes Institute, Norwich, UK. The sources of the other Streptomyces used in this study are shown in Table 2. With one exception, all strains were maintained on NE agar (Skeggs et al., 1985). S. karnatakensis was cultivated on sporulation agar (SA) which contained (per litre): $1 \mathrm{~g}$ yeast extract, $1 \mathrm{~g}$ beef extract, $2 \mathrm{~g}$ tryptose, $100 \mathrm{mg}$ $\mathrm{FeSO}_{4} \cdot 7 \mathrm{H}_{2} \mathrm{O}, 10 \mathrm{~g}$ glucose, $20 \mathrm{~g}$ agar, adjusted to $\mathrm{pH} 7.3$ with $\mathrm{KOH}$.

Plasmid pLST801 was constructed from pTZ18 (Mead et al., 1986) essentially by deleting the bla gene and replacing it with aph from $\operatorname{Tn} 5$. This plasmid therefore encodes a single polypeptide, namely, the product of the aph gene which is itself governed by the lac promoter.

Antibiotics used were althiomycin, amicetin, blasticidin S, bottromycin, chartreusin, lincomycin, pactamycin, sparsomycin (all from Upjohn), carbomycin (Pfizer), spiramycin (May and Baker) and tetracycline (Sigma).

Growth of cells and preparation of extracts. Spores and aerial mycelium scraped from one confluent agar plate were used to inoculate $2 \times 1$ litre YEME/PEG medium (Thompson et al., 1984) in a 21 baffled flask. Incubation 
was at $30^{\circ} \mathrm{C}$ for $14-16 \mathrm{~h}$ in a New Brunswick orbital shaker at 200-220 r.p.m. All subsequent manipulations were carried out at $0-4{ }^{\circ} \mathrm{C}$. Mycelium was harvested, washed three times by centrifugation through 'washing buffer' [ $10 \mathrm{mM}$-HEPES/KOH pH 7.6 at $20^{\circ} \mathrm{C}, 10 \mathrm{mM}-\mathrm{MgCl}_{2}, 1 \mathrm{M}-\mathrm{KCl}, 10 \%$ (v/v) glycerol and $5 \mathrm{~mm}-2$-mercaptoethanol] and twice through 'S30 buffer' [50 mM-HEPES/KOH pH 7.6 at $20^{\circ} \mathrm{C}, 10 \mathrm{~mm}-\mathrm{MgCl}_{2}, 60 \mathrm{~mm}-\mathrm{NH}_{4} \mathrm{Cl}, 10 \%(\mathrm{v} / \mathrm{v})$ glycerol and $5 \mathrm{mM}-2$-mercaptoethanol], resuspended in $2.5 \mathrm{ml} \mathrm{S} 30$ buffer per $\mathrm{g}$ wet weight, and passed through a chilled French press at 70-80 MPa (10000-12000 p.s.i.). The lysate was then centrifuged at 15000 r.p.m. for 30 min in a Beckman SW 27 rotor. The supernatant was removed and recentrifuged under similar conditions, thereby generating a $30000 \mathrm{~g}$ supernatant (designated S30) which was treated with micrococcal nuclease (as described previously, Thompson et al., 1984) to remove endogenous mRNA and DNA that could otherwise contribute to protein synthesis. When mycelium was destined for the preparation of crude initiation fractors or salt-washed ribosomes, the number of centrifugation washes was reduced by one for each buffer and glycerol was omitted from the buffers.

Preparation of ribosomes, ribosomal subunits and post-ribosomal supernatant. Post-ribosomal supernatant (S100) and unwashed ribosomes were prepared by centrifugation of a nuclease-treated extract at 50000 r.p.m. for $2 \mathrm{~h}$ at $4{ }^{\circ} \mathrm{C}$ in a Beckman Ti75 rotor. The supernatant was used as a source of RNA polymerase and soluble factors for protein synthesis. The pellet of unwashed ribosomes was resuspended in HRS buffer (10 mM-HEPES/KOH pH 7.6 at $20^{\circ} \mathrm{C}, 10 \mathrm{mM}-\mathrm{MgCl}_{2}, 50 \mathrm{mM}-\mathrm{NH}_{4} \mathrm{Cl}, 5 \mathrm{~mm}$-2-mercaptoethanol). Both fractions were divided into small portions and stored at $-70^{\circ} \mathrm{C}$. Salt-washed ribosomes and ribosomal subunits were prepared as described previously (Skeggs et al., 1985).

Preparation of crude initiation factors. This procedure was'modified from one described for the preparation of similar factors from Bacillus subtilis (Legault-Demare \& Chambliss, 1974). All manipulations were carried out at $0-4{ }^{\circ} \mathrm{C}$. Unwashed ribosomes in HRS buffer were stirred slowly for $16 \mathrm{~h}$, collected by centrifugation at 40000 r.p.m. for $5 \mathrm{~h}$ in a Beckman Ti75 rotor and then resuspended in 'high-salt buffer' $(10 \mathrm{~mm}-\mathrm{HEPES} / \mathrm{KOH} \mathrm{pH}$ 7.6 at $20^{\circ} \mathrm{C}, 10 \mathrm{mM}-\mathrm{MgCl}_{2}, 1 \mathrm{M}-\mathrm{NH}_{4} \mathrm{Cl}, 5 \mathrm{~mm}$-2-mercaptoethanol) and stirred slowly, again for $16 \mathrm{~h}$. Ribosomes were removed from the preparation by centrifugation as above and $\left(\mathrm{NH}_{4}\right)_{2} \mathrm{SO}_{4}$ was slowly added to the upper four-fifths of the supernatant, until a final saturation of $80 \%$ was reached. After stirring for $1.5 \mathrm{~h}$, the precipitate was collected by centrifugation at 15000 r.p.m. for $15 \mathrm{~min}$ in a Beckman JA21 rotor, resuspended in and extensively dialysed against $\mathrm{HRS}$ buffer and stored at $-70{ }^{\circ} \mathrm{C}$ in small portions.

Assay of coupled transcription-translation. Reactions were performed under the conditions described previously (Thompson et al., 1984) using pBR322 or pUC18 as template except that the final concentrations of ammonium acetate and potassium acetate in the reaction mixture were $140 \mathrm{~mm}$ and $280 \mathrm{~mm}$ respectively, instead of $48 \mathrm{~mm}$ and $95 \mathrm{~mm}$ as previously used. Reaction mixtures contained $2 A_{260}$ units of S30 or 20-25 pmol ribosomes (or ribosomal subunits), plus S100 and crude initiation factors. The inputs of the latter two fractions were optimized for each preparation, using a fixed input of ribosomes. Analysis of reaction products by polyacrylamide gel electrophoresis was carried out as described previously (Thompson et al., 1984). To minimize endogenous protein synthesis in extracts which were not amenable to nuclease treatment, $2 A_{260}$ units of S30 was incubated with $8 \mu 1$ synthesis mix (see Thompson et al., 1984) for $15 \mathrm{~min}$ at $30^{\circ} \mathrm{C}$ prior to the addition of the remaining reaction components.

Test for pactamycin inactivation. S30 $(25 \mu \mathrm{l})$ from $S$. karnatakensis or $S$. pactum containing $2 \mu \mathrm{g}$ pactamycin was incubated in the presence of putative cofactors for drug inactivation (i.e. acetyl-CoA, ATP and $S$-adenosylmethionine, each at $1 \mathrm{~mm}$ final concentration) for $30 \mathrm{~min}$ at $30^{\circ} \mathrm{C}$. The extent of inactivation of $1 \mu \mathrm{g}$ pactamycin was then tested by microbiological assay using antibiotic assay discs placed on nutrient agar freshly seeded with Micrococcus luteus. Plates were incubated at $30^{\circ} \mathrm{C}$ overnight.

\section{RESULTS}

When methodology for the production of $S$. lividans extracts (S30), capable of coupled transcription-translation in response to plasmid DNA, was first developed in this laboratory (Thompson et al., 1984), problems were initially encountered due to 'background' levels of protein synthesis due, presumably, to residual endogenous mRNA. Eventually, this problem was circumvented by the use of micrococcal nuclease which, under controlled conditions, reduced the background to minimal levels so that plasmid-dependent protein synthesis could readily be monitored following inactivation of the nuclease. Since then, S30 extracts with similar properties have been produced from several other actinomycetes, using similar methods. However, not all strains have been amenable to such treatment. As part of a more general survey of possible resistance mechanisms among Streptomyces, extracts were prepared from five strains that synthesize antibiotics (all of them inhibitors of protein synthesis) for which no resistance mechanisms have yet been described. The organisms concerned and the respective autogenous products were: Streptomyces althioticus (althiomycin), Streptomyces bottropensis (bottromycin), 


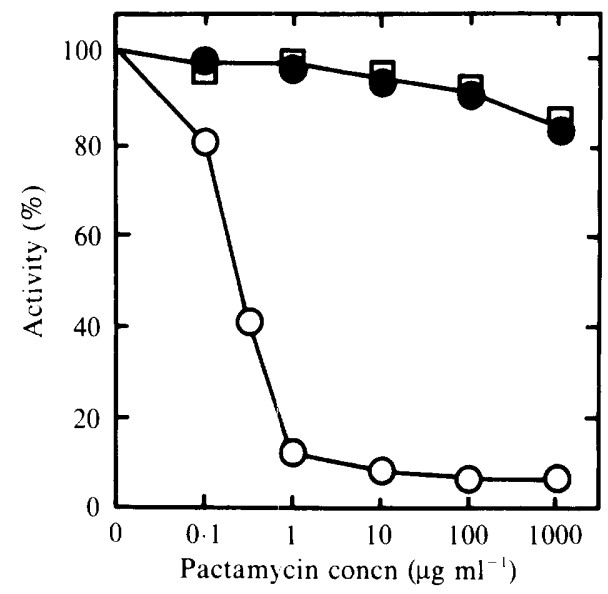

Fig. 1. Pactamycin sensitivity of coupled transcription-translation by Streptomyces extracts. Cell-free extracts of $S$. karnatakensis $(\square)$, S. lividans $(O)$ and $S$. pactum $(\bigcirc)$ were incubated with pactamycin for $10 \mathrm{~min}$ prior to addition of reaction components $(100 \%$ activity refers to the incorporation of $\left[{ }^{35}\right]$ methionine into TCA-precipitable material in a drug-free control).

Streptomyces sparsogenes (sparsomycin) and Streptomyces pactum plus Streptomyces karnatakensis (both being producers of pactamycin). Although crude S30 extracts prepared from each of these strains were capable of protein synthesis, it was not possible selectively to remove the background (i.e. plasmid-independent) component by treatment with micrococcal nuclease. Rather, as nuclease treatment proceeded, there was a concomitant reduction in both the plasmid-dependent and the endogenous activities (data not given). Fortunately, however, it was not necessary to investigate the reasons underlying such behaviour since an alternative approach proved successful.

In the modified procedure, $\mathrm{S} 30$ extracts from the five strains were pre-incubated for $10 \mathrm{~min}$ at $30{ }^{\circ} \mathrm{C}$ with all of the components ('synthesis mix', see Methods) normally needed for coupled transcription-translation, but in the absence of plasmid. This resulted in a drastic reduction (to about $20 \%$ of the original level) in background activity, presumably reflecting run-off translation and/or the degradation of endogenous mRNA in the extracts. Then, following the addition of plasmid, coupled transcription-translation in those extracts could readily be monitored in the presence and absence of the autogenous drugs.

In extracts from $S$. althioticus, $S$. bottropensis and $S$. sparsogenes, coupled transcriptiontranslation was just as sensitive to althiomycin, bottromycin or sparsomycin, respectively, as was the corresponding activity in S30 extracts from $S$. lividans (data not given). These extracts were also incapable of inactivating the drugs (Micrococcus luteus was the indicator strain) even when supplemented with putative cofactors, such as ATP or acetyl-CoA (data not given). Accordingly, these three antibiotic producers did not appear to possess any obvious intracellular resistance mechanisms, at least under the growth conditions employed. The latter point is important. Specific antibiotic-production media were not used in the generation of the mycelia and it therefore remains possible that intracellular resistance might have been induced in any of the three strains had we done so. Alternatively, these organisms might employ membrane permeability barriers coupled with efficient antibiotic efflux mechanisms (and/or metabolic shielding - see Cundliffe, 1984) in order to tolerate their products. In contrast, however, coupled transcription-translation in S30 extracts from the two pactamycin producers ( $S$. pactum and $S$. karnatakensis) was highly resistant to pactamycin, in comparison with the response in $S$. lividans extracts (Fig. 1). This result is particularly interesting, given that extracts from the two pactamycin producers did not detoxify the drug as judged by microbiological assay against $M$. luteus. Thus, the obvious possibility was suggested that the pactamycin producing-organisms might possess pactamycin-resistant ribosomes, whether or not they also utilized any additional device to avoid suicide. Moreover, the putative ribosomal resistance character seemed to be 
Table 1. Typical activities of subcellular components from S. lividans in coupled transcription-translation reactions

\begin{abstract}
One hundred percent activity is equivalent to $6 \mathrm{pmol}$ methionine incorporated into hot TCAprecipitable material in a $30 \mathrm{~min}$ reaction. Where appropriate, 20 pmol ribosomes or ribosomal subunits were present in the reaction.
\end{abstract}

$\begin{array}{lr}\quad \text { Subcellular fraction(s) } & \begin{array}{r}\text { Activity } \\ (\%)\end{array} \\ \text { S30 } & 100 \\ \text { S100 } & <5 \\ \text { Unwashed 70S ribosomes } & 8 \\ \text { S100 plus unwashed 70S ribosomes } & 92 \\ \text { Ribosomal wash fraction plus S100 } & <5 \\ \text { Salt-washed 70S ribosomes } & <5 \\ \text { Salt-washed 70S ribosomes plus S100 } & 21 \\ \text { Salt-washed 70S ribosomes, S100 plus ribosomal wash fraction } & 64 \\ \text { 30S plus 50S ribosomal subunits plus S100 } & 5 \\ \text { 30S plus 50S ribosomal subunits plus S100 plus ribosomal wash fraction } & 48\end{array}$

constitutively expressed, in the sense that its appearance was not obviously dependent upon any specific physiological stimulus.

The value of using coupled transcription-translation in the investigation of antibiotic resistance is illustrated particularly clearly in the context of pactamycin, since the drug does not normally affect alternative assay systems, such as poly(U)-dependent synthesis of polyphenylalanine. That said, however, the utility of crude S30 extracts (such as those used above) in this respect is severely limited. For example, it was not possible to conclude from the above data that the pactamycin producers possessed drug-resistant ribosomes. In order to analyse such resistance mechanisms in more detail, it was necessary to fractionate the assay system in order to study the contributions from individual components.

Characterization of a fractionated coupled transcription-translation system from S. lividans

Initially, crude S30 extracts were fractionated to yield unwashed ribosomes and S100 supernatant (see Methods), the latter being expected to contain soluble factors required for transcription (including RNA polymerase) or translation. Thereafter, the ribosomes were washed in buffer of high ionic strength to yield 'salt-washed ribosomes' and the 'ribosomal wash fraction'. By analogy with other bacterial systems, the wash fraction was expected to contain initiation factors for protein synthesis (see below) although, in the present context, that point needed to be established directly. Finally, the salt-washed $70 \mathrm{~S}$ ribosomes were dissociated into their $50 \mathrm{~S}$ and $30 \mathrm{~S}$ subunits. For present purposes, such a fractionation procedure was considered adequate since the immediate objective was to analyse translation in some detail. However, with minor modifications of the procedure (particularly involving the S100 fraction) additional components involved in transcription could presumably be isolated.

Once the various cell fractions had been prepared, several experiments were carried out to determine their optimal inputs for coupled transcription-translation, with attention focused primarily upon translation. First, using a fixed input of ribosomes ( $20-25$ pmol per assay; the equivalent of those present when unfractionated S30 had been used previously) optimal inputs of S100 were determined (to complement unwashed ribosomes). Using this optimal amount of S100, the system based upon unwashed ribosomes possessed activity comparable with the unfractionated extract (Table 1) whereas when 'salt-washed' ribosomes were included in place of unwashed particles, the activity of the system was reduced by about $80 \%$. Since the saltwashed ribosomes had been subjected to an extra purification step, the lower activity was probably due to removal of ribosome-associated factors essential for translation - a notion that is supported by the finding that the ribosome-wash fraction stimulated the activity of salt-washed ribosomes threefold (Table 1). The residual factors associated with the salt-washed ribosomes appear to be removed during ribosomal subunit preparation since the activity of purified $30 \mathrm{~S}$ 


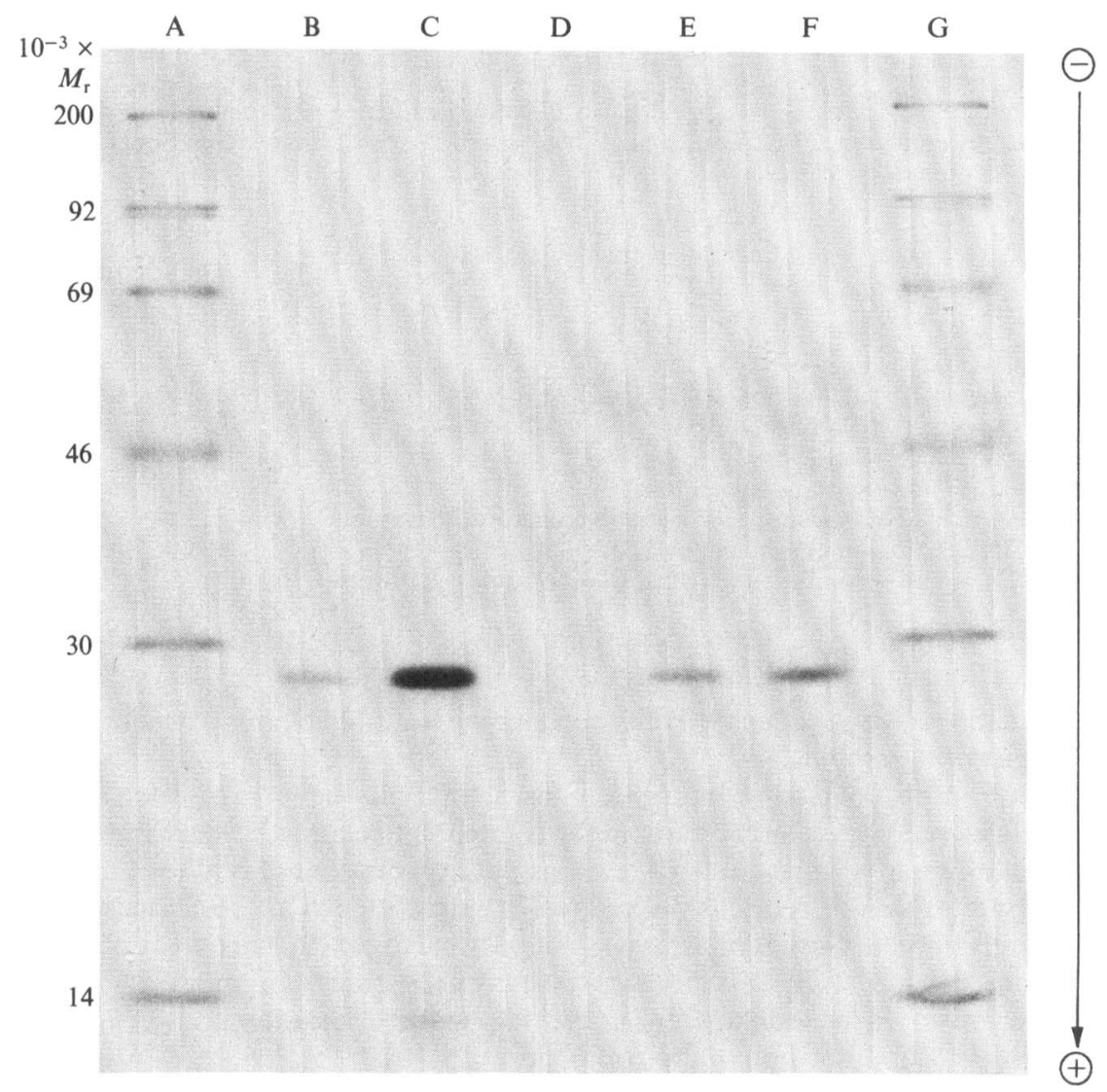

Fig. 2. Electrophoretic analysis of the product of coupled transcription-translation by fractionated cell extracts. Plasmid pLST801, containing the aminoglycoside phosphotransferase gene (aph) from transposon Tn 5 under the control of the lac promoter, was used as template. Reactions contained $\mathrm{S} 30$ (track B) unwashed ribosomes and S100 (C), salt-washed ribosomes, S100 and ribosomal wash fraction (E), 30 S plus 50 S ribosomal subunits, $S 100$ and ribosomal wash fraction (F). In the control track (D) S30 extract was incubated in the absence of added template. $\left[{ }^{14} \mathrm{C}\right]$ Protein markers were included in tracks (A) and $(\mathrm{G})$; these and reaction products were subjected to SDS-PAGE and visualized by fluorography.

and $50 \mathrm{~S}$ particles (in combination) was almost completely dependent upon the addition of ribosomal wash fraction. That the stimulatory components of the wash fraction were initiation factors was supported by the observation that a combination of ribosomal subunits and S100 was highly active in the poly(U)-directed formation of polyphenylalanine (a reaction which in other bacterial systems does not require initiation factors) and that the ribosomal wash fraction only increased this activity by approximately $20 \%$ (data not shown).

Although the ribosomal-wash fraction was not purified further, its effect on the coupled transcription-translation activity of unfractionated extracts was tested. Studies with an equivalent wash fraction from Bacillus subtilis have indicated that ribosomes from this organism are not saturated with initiation factors, at least not under the growth conditions employed for extract preparation (Legault-Demare \& Chambliss, 1974). This conclusion was drawn from the observation that the ribosomal-wash fraction caused a twofold stimulation in the translation of bacteriophage-derived mRNA by unwashed ribosomes and S100. A similar result was also obtained using extracts from Escherichia coli (Legault-Demare et al., 1973). Accordingly we addressed the question of initiation factor saturation with respect to $S$. lividans extracts. 
Table 2. Producing organisms with antibiotic-sensitive ribosomes Strains were obtained from the sources indicated (UC strains were obtained from the Upjohn
Company, Kalamazoo, Michigan, USA). Coupled transcription-translation reactions were performed
as described in Methods, using 20 pmol salt-washed ribosomes. Each organism possessed ribosomes
that were as sensitive to the autogenous antibiotic as were those from $S$. lividans. Activity is given as the
incorporation of $\left[{ }^{35}\right.$ S]methionine into hot TCA-precipitable material by ribosomes in the presence of
$10 \mu \mathrm{g}$ antibiotic $\mathrm{ml}^{-1}$, expressed as a percentage of the incorporation observed in a drug-free control.

Organism

S. althioticus UC 2343

S. ambofaciens NRRL 2420

S. bottropensis ATCC 25435

S. chartreusis NRRL 2287

S. fasciculatus NRRL 2413

S. halstedii NCIB 9344

S. lincolnensis UC 2376

S. morookaensis ATCC 19166

S. sparsogenes UC 2474

S. vellosus NRRL 8037

S. viridifaciens NCIB 8954
Antibiotic

Althiomycin

Spiramycin

Bottromycin

Chartreusin

Amicetin

Carbomycin

Lincomycin

Blasticidin S

Sparsomycin

Lincomycin

Tetracycline
Activity $(\%)$ of ribosomes

in the presence of

$10 \mu \mathrm{g}$ antibiotic $\mathrm{ml}^{-1}$

However, over a wide range of inputs the ribosomal-wash fraction had no discernible effect on the activity of unfractionated extracts or upon assays containing S100 plus unwashed ribosomes (data not shown). Consequently it seems unlikely that, under the growth conditions used for $S$. lividans in this study, ribosomes are limited by factor availability.

Having established that a coupled transcription-translation system could be set up using separated ribosomal subunits, initiation factors and $\mathrm{S} 100$, it was necessary further to establish that such a fractionated system was still operating properly, i.e. that the response of unfractionated S30 extracts to DNA templates was being faithfully mimicked. This was confirmed by subjecting the polypeptide products of reactions programmed with pLST801 $(1 \mu \mathrm{g})$ to electrophoresis in SDS-polyacrylamide gels (Fig. 2). This plasmid has a single resistance determinant (the aminoglycoside phosphotransferase gene from $\operatorname{Tn} 5$ ) under transcriptional control from the lac promoter (see Methods). A polypeptide with an $M_{\mathrm{r}}$ close to 29053, the size predicted from the nucleotide sequence of the aminoglycoside phosphotransferase gene (Beck et al., 1982), was observed as the major product, irrespective of the degree of fractionation of the system (the minor polypeptide species seen in track $\mathrm{C}$ were also present in the other tracks).

\section{Antibiotic responses of ribosomes from producing-organisms}

Thus far, the capacity for plasmid-dependent protein synthesis had been demonstrated exclusively with homologous combinations of components, i.e. all derived from $S$. lividans. Now, however, we wished to generate heterologous systems containing salt-washed ribosomes from different sources operating in the standard S. lividans 'background' of S100 plus initiation factors. This proved to be possible with ribosomes from several antibiotic-producing strains. For each organism listed in Table 2 , the ribosomes were fully susceptible to the autogenous antibiotic (taking S. lividans ribosomes as the sensitive standard) and in each case the system was strongly inhibited at about $10 \mu \mathrm{g}$ drug $\mathrm{ml}^{-1}$, which served to emphasize the overall sensitivity of the system to inhibitors of protein synthesis. Again, it must be stressed that the organisms listed in Table 2 had been grown in a standard laboratory medium prior to ribosomal extraction, with no attempt made to induce any putative resistance mechanism. Thus, we can only conclude that the organisms concerned do not demonstrate constitutively expressed resistance at the level of the ribosome. In contrast, however, the two pactamycin producers (S. pactum and S. karnatakensis) grown under similar 'non-inducing' conditions, yielded ribosomes that were highly resistant to 


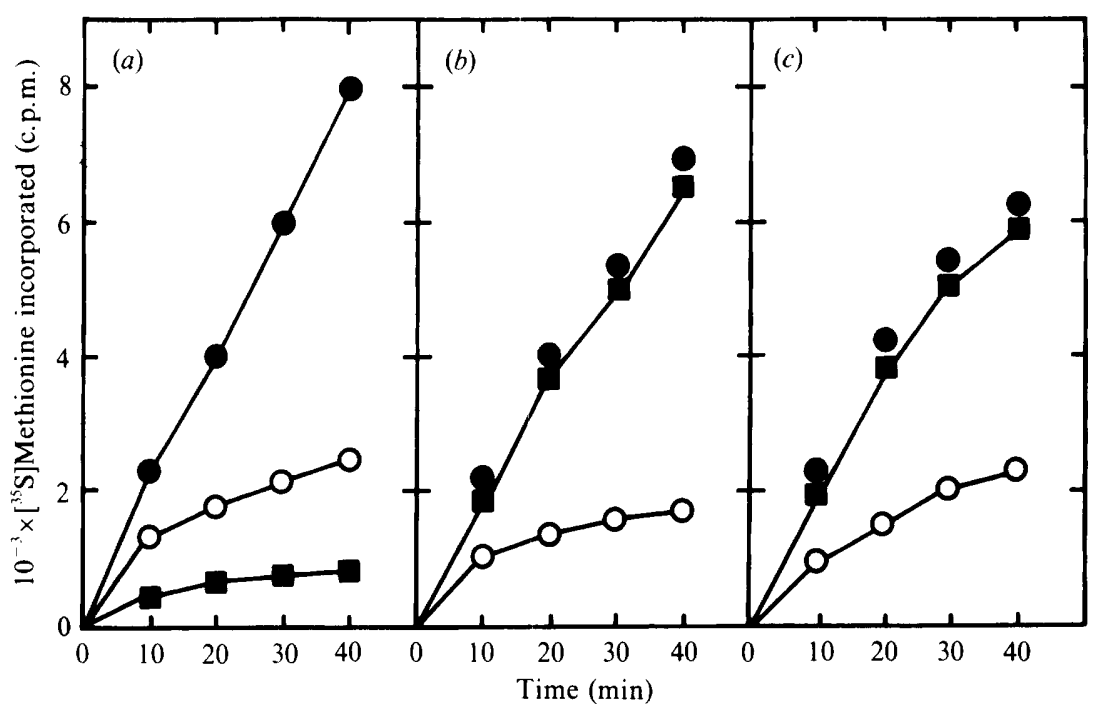

Fig. 3. Response of salt-washed ribosomes to pactamycin. Salt-washed ribosomes from $S$. lividans (a), $S$. pactum (b) or $S$. karnatakensis (c) were supplemented with $\mathrm{S} 100$ and ribosomal wash fraction (both from $S$. lividans) and assayed in the presence $(\square)$ and absence $(O)$ of pactamycin $\left(100 \mu \mathrm{g} \mathrm{ml}^{-1}\right.$ final concentration). The activity of each ribosome preparation in the absence of ribosomal wash fraction is also shown $(\mathrm{O})$.

pactamycin. Essentially similar responses to the drug were obtained with unwashed ribosomes (data not given) and with salt-washed particles (Fig. 3), suggesting strongly that resistance was due to some property of the ribosomes rather than any soluble factor. In addition, Fig. 3 shows that the activity of heterologous ribosomes was stimulated two- to threefold by the ribosomal wash fraction from $S$. lividans.

It also proved possible to generate active ribosomes containing $50 \mathrm{~S}$ and $30 \mathrm{~S}$ subunits derived from different strains and recombined in reciprocal fashion to yield $70 \mathrm{~S}$ hybrid particles. When such particles were prepared with ribosomal components from $S$. lividans and either of the pactamycin-producers, and the drug responses of homologous and heterologous pairings were compared, it became clear that resistance to pactamycin was conferred by the $30 \mathrm{~S}$ ribosomal subunits of $S$. pactum (Fig. 4) or $S$. karnatakensis (data not given; closely similar to those shown for $S$. pactum), there being no detectable contribution to resistance from the $50 \mathrm{~S}$ subunits. This result is entirely consistent with earlier data arising from antibiotic-binding studies in which pactamycin was found to recognize a single site on the smaller subunit of bacterial (Stewart \& Goldberg, 1973) or eukaryotic (Macdonald \& Goldberg, 1970) ribosomes.

Thus far, it has not been possible to carry the analysis of ribosomal resistance to pactamycin to its logical conclusion, namely, the identification of the macromolecule(s) responsible for resistance. To do this would require the reconstitution of $30 \mathrm{~S}$ ribosomal particles containing homologous and heterologous combinations of $16 \mathrm{~S}$ rRNA and proteins derived from, for example, $S$. pactum and $S$. lividans. These could then be combined with $50 \mathrm{~S}$ ribosomal subunits from $S$. lividans, challenged with drug, and assayed in coupled transcription-translation as above. However, although we have been able to reconstitute active $30 \mathrm{~S}$ particles from $S$. lividans, we were unable to do this with materials derived from either of the pactamycin producingorganisms. Nor were we able to generate active $30 \mathrm{~S}$ particles containing heterologous combinations of RNA and protein. Accordingly, there the matter rests, although one possible way ahead is apparent. If the resistance determinant(s) from $S$. pactum and/or $S$. karnatakensis could be cloned in $S$. lividans, and if the clones were found to possess pactamycin-resistant $30 \mathrm{~S}$ ribosomal subunits, reconstitution of active particles with combinations of RNA and protein derived from the clone and the parental strain might prove feasible. 


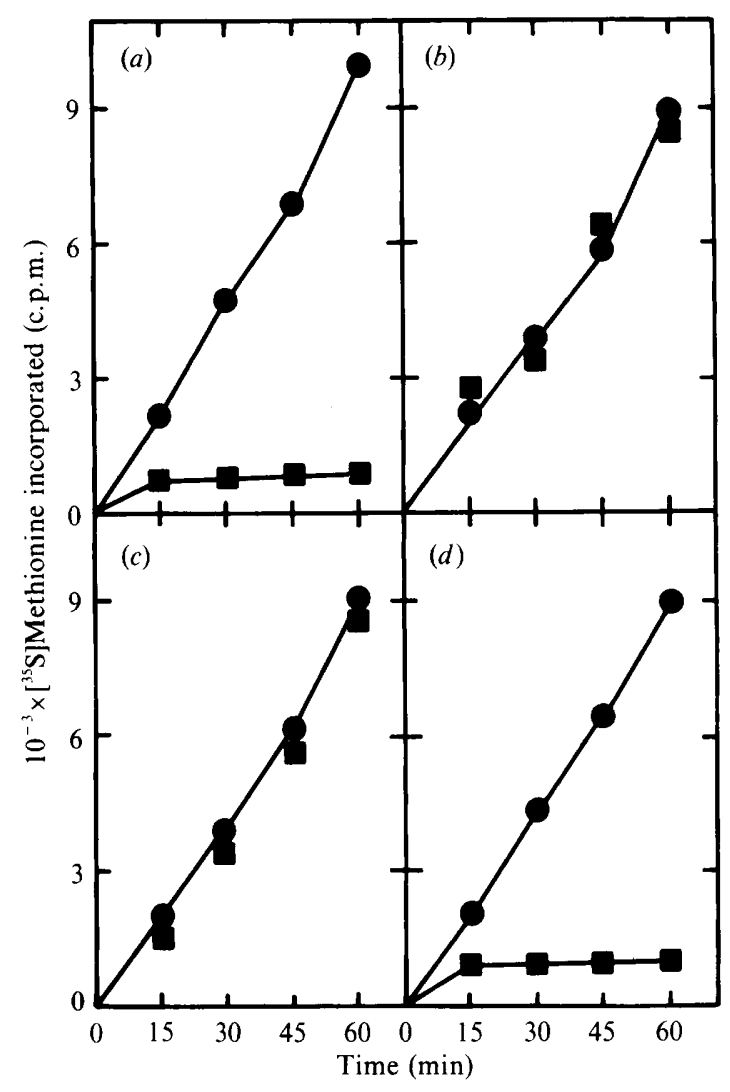

Fig. 4. Effect of pactamycin on protein synthesis by homologous and heterologous combinations of ribosomal subunits. All reactions contained S100 and ribosomal wash fraction from S. lividans. Ribosomal subunits were incubated with solvent $(O)$ or pactamycin at $10 \mu \mathrm{g} \mathrm{ml}^{-1}$ final concentration (a) prior to assay for coupled transcription-translation. Source of ribosomal subunits: (a) $30 \mathrm{~S}$ and $50 \mathrm{~S}$ from $S$. lividans; (b) $30 \mathrm{~S}$ and $50 \mathrm{~S}$ from $S$. pactum; (c) $30 \mathrm{~S}$ from $S$. pactum, $50 \mathrm{~S}$ from $S$. lividans; (d) $30 \mathrm{~S}$ subunits from $S$. lividans, $50 \mathrm{~S}$ from $S$. pactum.

\section{DISCUSSION}

Although, ultimately, it was not possible to resolve completely the mechanism of resistance to pactamycin in the respective producing-strains, that was not the sole objective of the present work. An important aim was realized, namely, the fractionation of the coupled transcriptiontranslation system, at least to the point where ribosomal subunits from different strains could be examined directly for their responses to specific drugs. Thus, the way is now clear for more detailed studies of antibiotic resistance mechanisms in strains that produce inhibitors of ribosomal function - especially where artificial protein synthetic systems [e.g. those directed by poly $(U)]$ are not sensitive to the drugs under investigation. To date, about 20 different actinomycetes have yielded ribosomes that function together with soluble factors from S. lividans in this way (M. Calcutt \& A. A. D. Beauclerk, unpublished data). Moreover, with only minor modifications, this type of assay system should become amenable to the study of resistance mechanisms involving inhibitors of RNA polymerase or other drugs whose action might be directed against non-ribosomal components of translation, such as elongation factors.

Obviously, we cannot yet know whether $S$. pactum and $S$. karnatakensis share a common mechanism of resistance to pactamycin or, indeed, what the mechanism might be. Previously, we have observed that various antibiotic-producing organisms defend themselves against their 
products via specific methylation of ribosomal RNA, in each case at a single, characteristic site. For the antibiotics thiostrepton (Thompson et al., 1982) and erythromycin (Skinner et al., 1983) the target is $23 \mathrm{~S}$ rRNA whereas, in some strains that produce aminoglycosides, 16S rRNA is modified (Beauclerk \& Cundliffe, 1987). Whether or not methylation of 16S rRNA underlies resistance to pactamycin remains to be established. However, it is at least clear that a novel resistance mechanism is involved, since neither of the pactamycin producers is resistant to aminoglycosides or to other drugs (several such were tested) that normally act against $30 \mathrm{~S}$ ribosomal subunits (for review, see Gale et al., 1981). We also note that pactamycin-resistant ribosomes have not been observed from any source other than $S$. pactum and $S$. karnatakensis. Evidently, a crucial region of the ribosome is involved in binding the drug; pactamycin is an extremely potent inhibitor (although its detailed mode of action has not been established) and its binding site has been conserved during three billion years or so of ribosomal evolution. The elucidation of the resistance mechanism(s) in the pactamycin producing-organisms will therefore be important not only in helping to define the target site for the drug but also in revealing one of the active sites of the ribosomal enzyme.

During the course of this work, M.J.C. received a research studentship from the MRC.

\section{REFERENCES}

Beauclerk, A. A. D. \& Cundliffe, E. (1987). Sites of action of two ribosomal RNA methylases responsible for resistance to aminoglycosides. Journal of Molecular Biology 193, 661-671.

Beck, E., Ludwig, G., Auerswald, E. A., Keiss, B. \& SCHALLER, H. (1982). Nucleotide sequence and exact localisation of the neomycin phosphotransferase gene from transposon Tn5. Gene 19, 327-336.

BibB, M. J. \& Cohen, S. N. (1982). Gene expression in Streptomyces: construction and application of promoter-probe plasmid vectors in Streptomyces lividans. Molecular and General Genetics 187, 265277.

Bibb, M. J., Jones, G. M., Joseph, R., Buttner, M. J. \& WARD, J. M. (1987). The agarase gene $(\operatorname{dag} A)$ of Streptomyces coelicolor A3(2): affinity purification and characterization of the cloned gene product. Journal of General Microbiology 133, 2089-2096.

Chambers, D. A. \& Zubay, G. (1969). The stimulatory effect of cyclic adenosine $3^{\prime} 5^{\prime}$-monophosphate on DNA-directed synthesis of $\beta$-galactosidase in a cellfree system. Proceedings of the National Academy of Sciences of the United States of America 63, 118-122.

Cozzone, A. J. (1980). Stringent control and protein synthesis in bacteria. Biochimie 62, 647-664.

Cundliffe, E. (1984). Self defence in antibioticproducing organisms. British Medical Bulletin 40, $61-67$.

Cundliffe, E. \& McQuillen, K. (1967). Bacterial protein synthesis: the effects of antibiotics. Journal of Molecular Biology 30, 137-146.

Gale, E. F., Cundliffe, E., Reynolds, P. E., Richmond, M. H. \& WaRING, M. J. (1981). The Molecular Basis of Antibiotic Action. London \& New York: John Wiley.

Gourse, R. L., Sharrock, R. A. \& Nomura, M. (1986). Control of ribosome synthesis in Escherichia coli. In Structure, Function, and Genetics of Ribosomes, pp. 766-788. Edited by B. Hardesty \& G. Kramer. New York: Springer-Verlag.

JONES, G. H. \& HopwOOD, D. A. (1984). Activation of phenoxazinone synthase expression in Streptomyces lividans by cloned DNA sequences from Strepto- myces antibioticus. Journal of Biological Chemistry 259, 14158-14164.

Legault-Demare, L. \& Chambliss, G. H. (1974). Natural messenger ribonucleic acid-directed cellfree protein-synthesising system of Bacillus subtilis. Journal of Bacteriology 120, 1300-1307.

Legault-Demare, L., Jeantet, C. \& Gros, F. (1973). Metabolic fate of initiation factors after inhibition of protein synthesis in Escherichia coli. Molecular and General Genetics 125, 301-318.

Lodish, H. F., Housman, D. \& JaCobsen, M. (1971). Initiation of hemoglobin synthesis. Specific inhibition by antibiotics and bacteriophage ribonucleic acid. Biochemistry 10, 2348-2356.

Macdonald, J. S. \& GoldberG, I. H. (1970). An effect of pactamycin on the initiation of protein synthesis in reticulocytes. Biochemical and Biophysical Research Communications 41, 1-8.

Mead, D. A., Szczesna-Skorupa, E. \& Kemper, B. (1986). Single stranded DNA 'blue' T7 promoter plasmids: a versatile tandem promoter system for cloning and protein engineering. Protein Engineering 1, 67-74.

Sinclair, R. B. \& BiBB, M. J. (1988). The repressor gene $(c)$ of the Streptomyces temperate phage $\phi \mathrm{C} 31$ : nucleotide sequence, analysis and functional cloning. Molecular and General Genetics 213, 269-277.

SkegGs, P. A., Thompson, J. \& CundlifFe, E. (1985). Methylation of $16 \mathrm{~S}$ ribosomal RNA and resistance to aminoglycoside antibiotics in clones of Streptomyces lividans carrying DNA from Streptomyces tenebrarius. Molecular and General Genetics 200 , 415-421.

Skinner, R., Cundliffe, E. \& Schmidt, F. J. (1983). Site of action of a ribosomal RNA methylase responsible for resistance to erythromycin and other antibiotics. Journal of Biological Chemistry 258, 12702-12706.

Stewart, M. L. \& Goldberg, I. H. (1973). Pactamycin binding to Escherichia coli ribosomes: interference by formation of the protein synthesising complex with $\mathrm{f} 2$ viral RNA. Biochimica et biophysica acta 294, 123-137. 
TaI, P.-C., Wallace, B. J. \& Davis, B. D. (1973) Actions of aurintricarboxylate, kasugamycin, and pactamycin on Escherichia coli polysomes. Biochemistry 12, 616-620.

Thiara, A. S. \& Cundliffe, E. (1988). Cloning and characterisation of a DNA gyrase B gene from Streptomyces sphaeroides that confers resistance to novobiocin. EMBO Journal 7, 2255-2259.

Thompson, J., SchmidT, F. \& CundlifFe, E. (1982). Site of action of a ribosomal RNA methylase conferring resistance to thiostrepton. Journal of Biological Chemistry 257, 7915-7917.

Thompson, J., RaE, S. \& Cundliffe, E. (1984). Coupled transcription-translation in extracts of Streptomyces lividans. Molecular and General Genetics 195, 38-43.
Vara, J. A., Pulido, D., LaCalle, R. A. \& Jimenez, A. (1988). Two genes in Streptomyces alboniger puromycin biosynthesis pathway are closely linked. Gene 69, 135-140.

YanG, H.-L., Zubay, G., Vrin, E., Reiness, G. \& CASHEL, M. (1974). Effects of guanosine tetraphosphate, guanosine pentaphosphate, and $\beta$ - $\gamma$-methylenyl-guanosine pentaphosphate on gene expression in Escherichia coli in vitro. Proceedings of the National Academy of Sciences of the United States of America 71, 63-67.

Zalacain, M., Malpartida, F., Pulido, D. \& JimeneZ, A. (1987). Cloning and expression in Escherichia coli of a hygromycin B phosphotransferase gene from Streptomyces hygroscopicus. European Journal of Biochemistry 162, 413-418. 